\title{
A BRIEF NOTE ON COPYRIGHT LAW AND THE PURPOSE OF THIS BOOK
}

In a nutshell, anything you write on paper or at a computer (or compose or record or sketch or paint or photograph) is protected by copyright law, which means that you can sue someone who unfairly copies from your work. The Constitution authorizes Congress to provide this protection, and during the first session (March 4, 1789, to March 4, 1791) of the newly formed Congress, the legislature granted book authors and map makers (but only book authors and map makers) a 14-year term of copyright for their writings. ${ }^{1}$

The founders' main theory was that without adequate incentives, creative people would not produce the optimal amount of new stuff. Without protection, artists and authors would get ripped off by copyists and lose heart (and dollars). A corollary of their incentive theory provides that when copyright expires, the protected work shifts into the public domain for us to enjoy for free and-just as important-for the next generation of artists to use as the basis for yet more creation. That's the copyright bargain baked into the Constitution, which states in article 1 , section 1 , clause 8 , that Congress can enact copyright laws only "to promote the progress of Science [meaning "knowledge" at the time it was written]."

This book uses data and empirical methods to ask big questions about copyright. What sort of copyright laws best promote public welfare? Why shouldn't all copying be prohibited? What is the best way to both protect authors and promote creativity?

Justices O'Connor and Brennan provided an important backdrop to these questions by explaining that in the US, the primary purpose of copyright is to increase public welfare, not to make authors rich: "It may seem unfair that much of the fruit of the compiler's labor may be used by others without compensation. 
[However], this is not 'some unforeseen byproduct of a statutory scheme.' It is, rather, 'the essence of copyright', and a constitutional requirement. The primary objective of copyright is not to reward the labor of authors, but 'to promote the Progress of Science and useful Arts."'2

Nowadays, authors, musicians, dramatists, choreographers, painters, sculptors, architects, and photographers all have strong protection that extends until 70 years after their deaths. ${ }^{3}$ Since the founding of our country, both the length and breadth of copyright protection has expanded, with more extensive protection proposed every year (see table 0.1).

Copyright law is not so complicated that the layperson is unable to determine what sort of legal protection is sensible and what sort is merely the result of industry capture of Congress. The goal of this book is to tell the story of copyright through empirical research (illustrated with interesting case studies of familiar works) and thereby to provide the reader with the tools for judging the wisdom of past and future copyright legislation.

The introduction to this book starts with one of the most surprising stories about copyright-how it diminishes the availability of important books to the public. Subsequent chapters identify other consumer welfare problems caused by overprotection of copyright: orphan photographs with unfindable owners (chapter 1); ambiguous infringement rules that drive musicians crazy (chapter 2); and ludicrous-yet dangerous - claims publishers make over public domain works (chapter 6). Although too much copyright clearly causes problems, the

TA B LE 0.1. Dates When Congress First Enacted Copyright Protection.

1. Literary works (books, maps, and charts) (1790)

2. Musical works, including any accompanying words (1831)

3. Dramatic works, including any accompanying music (1856)

4. Pantomimes and choreographic works (1976)

5. Pictorial, graphic, and sculptural works $(1865 ; 1871)$

6. Motion pictures and other audiovisual works (1912)

7. Sound recordings (1971)

8. Architectural works (1990)

Source: 17 U.S.C. $\$ 106(2018)$. 
empirical story is not all sadness. Rights reversion statutes bring books back into print (chapter 3 ), and the study of parody (including porn parodies!) reveals a healthy resilience in the copyright system (chapters 4 and 5). The book then fills out the complex empirical story of how creativity is fostered in the US by explaining how the music industry thrived despite the infringement onslaught of peer-to-peer file sharing (chapter 8); how the lack of legal protection for public domain photographs created massive value on Wikipedia (chapter 7 ); and how the lack of legal protection for public domain music influenced the film industry (chapter 10).

The book ends with the story of the author's personal involvement in a Don Quixote-style attempt to convince the Supreme Court that the Sonny Bono Copyright Term Extension Act is unconstitutional and offers a rather implausible conspiracy theory that links copyright law to Second Amendment rights.

In between the entertaining anecdotes, the overall goal of the book should be easy to discern. A data-driven view of copyright should convince the reader to exclaim at least once, "Boy, that part of copyright law is total nonsense!" 
This page intentionally left blank 
COPY THIS BOOK! 
This page intentionally left blank 